\title{
PENGARUH PERBEDAAN VARIETAS DAN STARTER PADA SILASE TEBON JAGUNG TERHADAP KADAR ABU, KADAR LEMAK KASAR, DAN KADAR BAHAN EKSTRAK TANPA NITROGEN
}

\section{The Effect of Variety and Starter Differences in Corn Silage on Ash, Ether Extract and Nitrogen Free Extract Content}

\author{
Neily Zulfa Umala, Farida Fathul, Agung Kusuma Wijaya dan Liman \\ Departement of Animal Husbandry, Faculty of Agriculture, University of Lampung \\ J1. Prof. Dr. Soemantri Brojonegoro No. 1 Gedong Meneng Bandar Lampung 35145 \\ e-mail : neilyzumala97@gmail.com
}

\begin{abstract}
This study aimed to investigate the content of ash, ether extract, and nitrogen free extract in corn silage with two varieties (BISI-18 and NK-212) given two types of starter (molasses and rice bran). This research was conducted in May-August 2019 at the Laboratory of Animal Nutrition and Feed, Department of Animal Husbandry, Faculty of Agriculture, University of Lampung. The factors studied were (1) corn stover varieties which consisted of two varieties (BISI-18 and NK-212) and (2) starter which consisted of two types of starter (molasses and rice bran). The results of this study showed that there was no interaction $(\mathrm{P}>0.05)$ between the use of varieties of corn forage and starter on ash, ether extract, and nitrogen free extract of silage. The use of different corn varieties had a significant effect $(\mathrm{P}<0.05)$ on silage ash, but it had no significant effect $(\mathrm{P}>0.05)$ on ether extract and nitrogen free extract of silage. The use of different types of starter has no significant effect $(\mathrm{P}>0.05)$ on ash, ether extract and nitrogen free extract of silage.
\end{abstract}

Keywords: Corn Silage, Silage Nutrition, Starter, Varieties

\section{ABSTRAK}

Penelitian ini bertujuan untuk mengetahui kadar abu, lemak kasar, dan bahan ekstrak tanpa nitrogen (BETN) pada silase tebon jagung dengan dua Varietas (BISI-18 dan NK-212) yang diberi dua jenis starter (molases dan dedak padi). Penelitian ini dilaksanakan pada Mei-Agustus 2019 di Laboratorium Nutrisi dan Makanan Ternak, Jurusan Peternakan, Fakultas Pertanian, Universitas Lampung. Rancangan percobaan yang digunakan adalah Rancangan Acak Lengkap (RAL) faktorial dengan 3 kali ulangan. Faktor yang diteliti adalah (1) varietas tebon jagung, yang terdiri dari dua varietas (BISI-18 dan NK-212) dan (2) starter, yang terdiri dari dua jenis starter (molases dan dedak padi). Hasil penelitian menunjukkan bahwa tidak ada interaksi $(\mathrm{P}>0,05)$ antara penggunaan varietas tebon jagung dan starter terhadap kadar abu, kadar lemak kasar, dan kadar BETN. Penggunaan varietas tebon jagung yang berbeda berpengaruh nyata $(\mathrm{P}<0,05)$ terhadap kadar abu silase, namun tidak berpengaruh nyata $(\mathrm{P}>0,05)$ terhadap kadar lemak kasar dan kadar BETN silase. Penggunaan jenis starter yang berbeda tidak berpengaruh nyata $(\mathrm{P}>0,05)$ terhadap kadar abu, kadar lemak kasar dan kadar BETN silase.

Kata kunci: Nutrisi Silase, Silase Tebon Jagung, Starter, Varietas

\section{PENDAHULUAN}

Pakan merupakan salah satu unsur terpenting dalam pemenuhan kebutuhan yang diperuntukkan untuk hidup pokok, produksi, dan reproduksi ternak. Hijauan merupakan sumber serat yang merupakan pakan utama bagi ternak ruminansia. Kandungan nutrisi yang cukup di dalam hijauan sangat disukai oleh ternak ruminansia. Selain itu juga, sangat dibutuhkan bagi produktivitas ternak ruminansia
(Kurnianingtyas, 2012). Tanaman jagung merupakan salah satu bahan pakan hijauan yang dapat dikonsumsi oleh ternak. Ketersediaan pakan hijauan pada saat musim penghujan sangat melimpah bahkan hingga mengalami pembusukan sebab ketersediaannya yang cukup banyak, sedangkan pada saat musim kemarau ketersediaan hijauan semakin berkurang untuk memenuhi kebutuhan ternak. Salah satu alternatif yang dapat dilakukan dalam memenuhi kebutuhan hijaun 
pakan ternak pada saat musim kemarau adalah dengan membuat silase tanaman jagung.

Silase adalah proses pengawetan hijauan pakan segar dalam kondisi anaerob dengan pembentukan atau penambahan asam. Asam yang terbentuk yaitu asam-asam organik antara lain laktat, asetat,dan butirat sebagai hasil fermentasi karbohidrat terlarut oleh bakteri sehingga mengakibatkan terjadinya penurunan derajat keasaman $(\mathrm{pH})$. Turunnya nilai $\mathrm{pH}$, maka pertumbuhan mikroorganisme pembusuk akan terhambat (Stefani dkk., 2010). Prinsip dasar pembuatan silase adalah fermentasi hijauan oleh mikroba yang banyak menghasilkan asam laktat. Mikroba yang paling dominan adalah dari golongan bakteri asam laktat homofermentatif yang mampu melakukan fermentasi dari keadaan aerob sampai anaerob. Asam laktat yang dihasilkan selama proses fermentasi akan berperan sebagai zat pengawet sehingga dapat menghindarkan dari bakteri pembusuk seperti clostridia dan enterobakteria.

Bakteri asam laktat sangat membantu dalam proses pembuatan silase. Bakteri asam laktat tumbuh dengan baik dengan bantuan starter yang mengandung gula. Berbagai macam starter yang dapat digunakan dalam proses pembuatan silase, diantaranya yaitu dedak padi dan molases. Bahan-bahan tersebut mengandung gula-gula sederhana yang dibutuhkan oleh bakteri asam laktat sehingga akan membantu dalam proses peningkatan kualitas silase. Berdasarkan hal tersebut maka peneliti ingin mengetahui pengaruh perbedaan varietas dan starter terhadap kualitas silase. Oleh sebab itu, dilakukanlah penelitian ini.

\section{MATERI DAN METODE}

Penelitian ini dilaksanakan pada bulan Mei-Agustus 2019. Penanaman jagung dilakukan di lahan dekat perumahan, dengan luas lahan $24 \times 8$ $\mathrm{m}^{2}$. Penanaman jagung dan pembuatan silase dilakukan di Desa Rejo Binangun, Kecamatan Raman Utara, Kabupaten Lampung Timur dan analisis proksimat dilaksanakan di Laboratorium Nutrisi dan Makanan Ternak, Jurusan Peternakan, Fakultas Pertanian, Universitas Lampung.

\section{Materi Penelitian}

Bahan yang digunakan dalam penelitian ini meliputi tebon jagung dengan umur panen 60 hari dengan varietas BISI-18 dan NK-212, starter berupa molases dan dedak padi, air, dan bahanbahan kimia untuk analisis lemak kasar (kertas saring dan chloroform). Peralatan yang digunakan pada penelitian ini adalah timbangan digital, timbangan analitik, karung plastik, alat pemotong, tali, terpal, serta alat uji analisis proksimat: oven, erlenmeyer, gelas ukur, corong, botol semprot, desikator, tanur, cawan porselen, kondensor, soxhlet, timbangan analitik dan kompor listrik.

\section{Metode Penelitian}

Penelitian ini menggunakan metode Rancangan Acak Lengkap (RAL) Faktorial 2x2. Perlakuan yang diberikan sebagai berikut:

Tebon jagung varietas BISI-18 dengan penambahan molases $16,87 \%$ dari berat kering tebon jagung (V1M1), tebon jagung varietas BISI18 dengan penambahan dedak padi $20,75 \%$ dari berat kering tebon jagung (V1M2), tebon jagung varietas NK-212 dengan penambahan molases 18,69\% dari berat kering tebon jagung (V2M1), dan tebon jagung varietas NK-212 dengan penambahan dedak padi $22,99 \%$ dariberat kering tebon jagung (V2M2). Penelitian ini menggunakan 4 kombi-nasi perlakuan dan 3 kali ulangan sehingga terdapat 12 unit percobaan. Jumlah bahan yang digunakan yakni hijauan tebon jagung sebanyak $84 \mathrm{~kg}$ berdasarkan berat layu. Masing-masing perlakuan dan ulangan menggunakan $7 \mathrm{~kg}$ bahan baku berdasarkan berat layu hijauan.

Kegiatan penelitian meliputi pembuatan silase tebon jagung dan tahap analisis proksimat yang meliputi kadar abu, kadar lemak kasar dan dilanjutkan dengan perhitungan kadar BETN silase. Data yang diperoleh dari hasil pengamatan disajikan dalam bentuk tabel dan dianalisis secara statistik. Data yang diperoleh dianalisis dengan sidik ragam pada taraf nyata 5\%. Jika hasilnya berbeda nyata dilakukan uji lanjut Duncan untuk mengetahui perlakuan terbaik (Muhtarudin dkk., 2011).

\section{HASIL DAN PEMBAHASAN}

\section{Pengaruh Perlakuan terhadap Kadar Abu Silase Tebon Jagung}

Hasil analisis ragam menunjukkan bahwa tidak ada interaksi $(\mathrm{P}>0,05)$ antara penggunaan varietas tebon jagung dan starter terhadap kadar abu silase. Hal ini menunjukkan bahwa penelitian penggunaan varietas dan starter tidak memengaruhi kadar abu silase. Rata-rata kadar abu silase hasil percobaan dapat dilihat pada Tabel 1. 
Tabel 1. Rata-rata kadar abu silase tebon jagung

\begin{tabular}{cccc}
\hline Perlakuan & Molases & Dedak Padi & Rata-rata \\
\hline & $--------(\%$ BK)--------- & \\
Varietas BISI-18 & 9,89 & 9,14 & $9,52 \pm 0,60^{\mathrm{a}}$ \\
Varietas NK-212 & 11,88 & 11,12 & $11,50 \pm 0,65^{\mathrm{b}}$ \\
\hline
\end{tabular}

Rata-rata

$10,89 \pm 1,03^{\mathrm{a}}$

$10,13 \pm 1,13^{\mathrm{a}}$

Keterangan: Nilai rata-rata dengan huruf superscript yang berbeda pada kolom atau baris yang sama menunjukkan berbeda nyata $(\mathrm{P}<0,05)$ dengan uji Duncan

Berdasarkan hasil uji lanjut Duncan diketahui bahwa varietas tebon jagung BISI-18 dan NK-212 memberikan pengaruh nyata $(\mathrm{P}<0,05)$ terhadap kadar abu silase. Data tersebut dapat dilihat pada Tabel 1 yang menunjukkan bahwa silase tebon jagung varietas BISI-18 menghasilkan kadar abu lebih rendah $(9,52 \pm 0,60 \%)$ jika dibandingkan dengan kadar abu pada silase tebon jagung varietas NK-212 $(11,50 \pm 0,65 \%)$. Hal tersebut menunjukkan bahwa varietas tebon jagung dapat memengaruhi kadar abu silase.

Hasil uji lanjut Duncan menunjukkan penggunaan starter molases dan dedak padi tidak memberikan pengaruh nyata $(\mathrm{P}>0,05)$ terhadap kadar abu silase tebon jagung. Data tersebut menunjukkan bahwa starter tidak dapat memengaruhi kadar abu silase tebon jagung. Hal ini sesuai dengan hasil penelitian Kuncoro dkk. (2015) yang menunjukkan bahwa starter EM-4 peternakan yang dikembang biakan dan starter cairan rumen kambing yang dikembang biakan tidak dapat memengaruhi kadar abu silase ransum basal (rumput gajah, limbah kulit kakao, kulit singkong, jenjet jagung, bungkil sawit, ampas tahu, onggok, molases, urea, dan mineral) dengan kadar abu masing-masing yaitu 8,33 dan 8,60\%.

Menurut Kuncoro dkk. (2015), kadar abu merupakan parameter untuk mengetahui mineral yang terkandung dalam suatu bahan yang mencirikan keberhasilan proses demineralisasi yang dilakukan. Menurut Superianto dkk. (2018), abu merupakan komponen anorganik yang tersusun dari bermacam mineral seperi $\mathrm{Ca}, \mathrm{P}, \mathrm{Mg}$ dan lainnya. Winarno (1992) menyatakan bahwa semakin rendah kadar abu yang dihasilkan maka mutu dan tingkat kemurnian akan semakin tinggi.

\section{Pengaruh Perlakuan terhadap Kadar Lemak Kasar Silase Tebon Jagung}

Hasil analisis ragam menunjukkan bahwa tidak ada interaksi $(\mathrm{P}>0,05)$ antara penggunaan varietas tebon jagung dan starter terhadap kadar lemak kasar silase. Hal ini menunjukkan bahwa penelitian penggunaan varietas dan starter tidak memengaruhi kadar lemak kasar silase. Rata-rata kadar lemak kasar silase hasil percobaan dapat dilihat pada Tabel 2 .

Tabel 2. Rata-rata kadar lemak kasar silase tebon jagung

\begin{tabular}{cccc}
\hline Perlakuan & Molases & Dedak Padi & Rata-rata \\
\hline & $--------(\%$ BK)------ & \\
Varietas BISI-18 & 7,77 & 7,74 & $7,76 \pm 0,63^{\mathrm{a}}$ \\
Varietas NK-212 & 7,80 & 8,66 & $8,23 \pm 0,84^{\mathrm{a}}$ \\
\hline Rata-rata & $7,79 \pm 0,43^{\mathrm{a}}$ & $8,20 \pm 0,97^{\mathrm{a}}$ & \\
\hline
\end{tabular}

Keterangan: Nilai rata-rata dengan huruf superscript yang sama pada kolom atau baris yang sama menunjukkan tidak berbeda nyata $(\mathrm{P}>0,05)$ dengan uji Duncan

Hasil uji lanjut Duncan menunjukkan bahwa tidak ada pengaruh nyata $(\mathrm{P}>0,05)$ pada varietas tebon jagung BISI-18 dan NK-212 terhadap kadar lemak kasar silase. Hal ini diduga, karena kadar lemak kasar kedua varietas tebon jagung tersebut tidak terlalu berbeda. Kadar lemak kasar pada tebon jagung BISI-18 adalah 5,78\% dan kadar lemak kasar pada tebon jagung NK-212 adalah 6,31\%. Nilai kadar lemak kasar pada tebon jagung BISI-18 dan NK-212 yang tidak jauh berbeda tersebut, memiliki hasil silase yang tidak berbeda nyata $(\mathrm{P}>0,05)$ terhadap kadar lemak kasar silase tebon jagung itu sendiri. Jika diperhatikan, masing-masing dari tebon jagung tersebut sebelum dijadikan silase dan sesudah dijadikan silase pada BISI-18 sama-sama memiliki kadar lemak kasar relatif lebih rendah jika dibandingkan dengan kadar lemak kasar pada NK212. Hal ini sesuai dengan pernyataan Leng (1991) yang menyatakan bahwa pembuatan silase dimaksudkan untuk mempertahankan kualitas atau bahkan meningkatkan kualitas pada pakan tersebut.

Berdasarkan hasil uji lanjut Duncan diketahui bahwa tidak ada pengaruh nyata $(\mathrm{P}>0,05)$ pada starter molases dan dedak padi 
terhadap kadar lemak kasar silase tebon jagung. Data tersebut menunjukkan bahwa starter tidak dapat memengaruhi kadar lemak kasar silase tebon jagung. Hal ini sesuai dengan hasil penelitian Nahak dkk. (2019) yang menunjukkan bahwa pemberian berbagai jenis starter yaitu dedak padi, tepung jagung, dan pollard tidak dapat memengaruhi kadar lemak kasar silase sorgum komplit, dengan masing-masing kadar lemak kasar sebesar 1,87, 2,25, dan 2,69\%. Jika diperhatikan, hasil kadar lemak kasar pada penelitian tersebut lebih rendah jika dibandingkan dengan data hasil kadar lemak kasar pada penelitian ini (Tabel 2).

Kadar lemak kasar berdasarkan uji proksimat pada penelitian ini menunjukkan bahwa nilai rataratanya di atas $7 \%$, baik dari jenis tebon jagung maupun dari starter molases dan dedak padi. Hasil tersebut tidak sesuai dengan pendapat Preston dan Leng (1987) yang menyatakan bahwa standar kandungan lemak kasar bahan pakan ternak ruminansia berkisar di bawah 5\%. Pernyataan tersebut menunjukkan bahwa hasil penelitian kadar lemak kasar silase tebon jagung yang diperoleh cukup tinggi. Hal ini diduga, karena adanya pengaruh dari kadar serat kasar silase tebon jagung tersebut.

Berdasarkan hasil analisis proksimat yang telah dilakukan, terjadi penurunan kadar serat kasar silase tebon jagung setelah dijadikan silase. Kadar serat kasar tebon jagung varietas BISI-18 adalah 29,27\%, dan NK-212 adalah 31,03\%. Kadar serat kasar tebon jagung yang telah dijadikan silase pada varietas BISI-18 adalah 29,16\% dan NK-212 adalah $28,65 \%$.

Kanisius dkk. (1983) menjelaskan bahwa serat kasar yang di dalamnya termasuk NDF (Neutral Detergent Fiber) dan ADF (Acid Detergent Fiber) merupakan zat atau bahan yang membentuk dinding sel tanaman, yang termasuk golongan ini adalah kutin, lignin, selulosa, hemiselulosa dan pentosan-pentosan. Said (1996) menyatakan bahwa hemiselulosa dapat difermentasi oleh beberapa mikroorganisme yang mampu menggunakan gula pentosa sebagai substratnya. Menurut Ranjhan dan Pathak (1979), adanya aktifitas mikroorganisme, karbohidrat komplek yang terdiri dari selulosa dan hemiselulosa akan dipecah menjadi asam lemak atsiri (asetat, propionate dan butirat). Menurut Ranjhan (1977), asam lemak atsiri merupakan sumber energi bagi ternak ruminansia dan mampu menyediakan energi 55-60\% dari kebutuhannya. Proses inilah yang menyebabkan kadar lemak kasar silase tebon jagung meningkat.

Menurut Kurniati (2016), kandungan lemak kasar yang terlalu tinggi pada bahan pakan ternak ruminansia tidak terlalu bagus karena dapat mengganggu proses fermentasi bahan pakan dalam rumen. Menurut hasil penelitian Anjalani dkk. (2017), kandungan lemak kasar silase rumput gajah dengan penambahan berbagai level starter umbi talas mendapatkan hasil terbaik yaitu pada level 5\% menghasilkan kadar lemak kasar sebesar $2,92 \%$.

\section{Pengaruh Perlakuan terhadap Kadar Bahan Ekstrak Tanpa Nitrogen Silase Tebon Jagung}

Hasil analisis ragam menunjukkan bahwa tidak ada interaksi $(\mathrm{P}>0,05)$ antara penggunaan varietas tebon jagung dan starter terhadap kadar BETN silase. Hal ini menunjukkan bahwa penelitian penggunaan varietas dan starter tidak dapat memengaruhi kadar BETN silase. Rata-rata kadar BETN silase hasil percobaan dapat dilihat pada Tabel 3.

Tabel 3. Rata-rata kadar BETN silase tebon jagung

\begin{tabular}{cccc}
\hline Perlakuan & Molases & Dedak Padi & Rata-rata \\
\hline Varietas BISI-18 & $---1 \%$ BK)------- & \\
Varietas NK-212 & 45,04 & 42,74 & $43,89 \pm 2,62^{\mathrm{a}}$ \\
Rata-rata & 42,32 & 40,12 & $41,22 \pm 2,73^{\mathrm{a}}$ \\
\hline
\end{tabular}

Keterangan: Nilai rata-rata dengan huruf superscript yang sama pada kolom atau baris yang sama menunjukkan tidak berbeda nyata $(\mathrm{P}>0,05)$ dengan uji Duncan

Hasil uji lanjut Duncan menunjukkan bahwa tidak ada pengaruh nyata $(\mathrm{P}>0,05)$ pada varietas tebon jagung BISI-18 dan NK-212 terhadap kadar BETN silase. Hal ini diduga, karena kadar BETN kedua varietas tebon jagung tersebut tidak terlalu berbeda. Kadar BETN pada 
tebon jagung BISI-18 adalah 38,43\% dan kadar BETN pada tebon jagung NK-212 adalah 36,44\%. Data tersebut menunjukkan bahwa varietas tebon jagug tidak dapat memengaruhi kadar BETN silase.

Hasil uji lanjut Duncan menunjukkan bahwa starter molases dan dedak padi tidak memberikan pengaruh nyata $(\mathrm{P}>0,05)$ terhadap kadar BETN silase tebon jagung. Hal ini diduga, karena tidak jauh berbeda antara kandungan BETN pada molases $(51,32 \%)$ dan dedak padi $(47,85 \%)$. Hasil penelitian ini sesuai dengan hasil penelitian Nahak dkk. (2019) yang menunjukkan bahwa starter dedak padi, tepung jagung, dan pollard tidak dapat memengaruhi kadar BETN silase komplit berbahan dasar sorgum, dengan kadar BETN pada penambahan starter dedak padi, tepung jagung, dan pollard masing-masing yaitu 54,85, 56,46, dan $53,95 \%$. Jika diperhatikan, kadar BETN pada penelitian tersebut lebih besar daripada hasil penelitian yang telah dilakukan (Tabel 3). Menurut Rahmadi (2003), kadar BETN yang rendah dipandang dari aspek nutrisi kurang menguntungkan, semakin sedikit BETN menunjukkan semakin sedikit komponen bahan organik yang dapat dicerna, mengakibatkan semakin sedikit pula energi yang dihasilkan.

Menurut hasil penelitian Anjalani dkk. (2017), kandungan BETN silase rumput gajah dengan penambahan berbagai level starter umbi talas mendapatkan hasil terbaik yaitu pada level $5 \%$ yang menghasilkan kadar BETN sebesar 36,49\%. Amrullah dkk. (2015) melaporkan bahwa kadar BETN pada silase limbah sayuran tanpa suplementasi adalah 42,37\%, kadar BETN silase limbah sayuran dengan penambahan dedak padi sebanyak $10 \%$ adalah $41,02 \%$, kadar BETN silase limbah sayuran dengan penambahan tepung gaplek sebanyak $10 \%$ adalah $56,98 \%$, dan silase limbah sayuran dengan penambahan molases sebanyak $10 \%$ adalah $47,89 \%$.

Anggorodi (2005) menyatakan bahwa BETN merupakan karbohidrat yang dapat larut meliputi monosakarida, disakarida dan polisakarida yang mudah larut dalam larutan asam dan basa serta memiliki daya cerna yang tinggi. Menurut Rahmadi (2003), kadar BETN yang rendah dipandang dari aspek nutrisi kurang menguntungkan, semakin sedikit BETN menunjukkan semakin sedikit komponen bahan organik yang dapat dicerna, mengakibatkan semakin sedikit pula energi yang dihasilkan.

\section{SIMPULAN}

Berdasarkan pada penelitian yang telah dilakukan, dapat diambil kesimpulan sebagai berikut :

1. Tidak terjadi interaksi $(\mathrm{P}>0,05)$ antara perlakuan varietas tebon jagung dan starter terhadap kadar abu, kadar lemak kasar dan kadar BETN silase.

2. Varietas tebon jagung memengaruhi $(\mathrm{P}<0,05)$ kadar abu silase, dengan varietas BISI-18 menghasilkan kadar abu $(9,52 \pm 0,60 \%)$ lebih rendah daripada NK-212 (11,50 $\pm 0,65 \%)$, akan tetapi varietas tebon jagung tidak memengaruhi $(\mathrm{P}>0,05)$ kadar lemak kasar dan kadar BETN silase.

3. Starter tidak memengaruhi $(\mathrm{P}>0,05)$ kadar abu, kadar lemak kasar dan kadar BETN silase.

\section{DAFTAR PUSTAKA}

Amrullah, F. A., Liman, dan Erwanto. 2015. Pengaruh penambahan berbagai jenis sumber karbohidrat pada silase limbah s ayuran terhadap kadar lemak kasar, serat kasar, protein kasar dan bahan ekstrak tanpa nitrogen. Jurnal Ilmiah Peternakan Terpadu 3 (4): 221-227.

Anggorodi, R. 2005. Ilmu Makanan Ternak Umum. Gadjah Mada University Peress. Yogyakarta.

Anjalani, R., L. Silitonga, dan M. H. Astuti. 2017. Kualitas silase rumput gajah yang diberi tepung umbi talas sebagai aditif silase. Jurnal Ilmu Hewani Tropika 6(1): 29-33.

Kanisius, A. A., H. S. Reksohadiprojo., S. Prawirokusumo., dan S. Lebdosoekadjo. 1983. Ilmu Makanan Ternak Dasar. Gadjah Mada University Press. Yogyakarta.

Kuncoro, D.C., Muhtarudin, dan F. Fathul. 2015. Pengaruh Penambahan Berbagai Starter pada Silase Ransum Berbasis Limbah Pertanian terhadap Protein Kasar, Bahan Kering, Bahan Organik, dan Kadar Abu. Jurnal Ilmiah Peternakan Terpadu 3(4): 234-238.

Kurniati. 2016. Kandungan Lemak Kasar, Bahan Organik, dan Bahan Ekstrak Tanpa Nitrogen Silase Pakan Lengkap Berbahan Utama Batang Pisang (Musa Paradisiaca) dengan Lama Inkubasi yang Berbeda. Skripsi. Fakultas Peternakan Universitas Hasanuddin. Makasar.

Kurnianingtyas, I.B. 2012. Pengaruh Macam Akselerator terhadap Nilai Nutrisi Silase Rumput Kolonjono (Brachiaria mutica) Ditinjau dari Nilai Kecernaan dan Fermentabilitas Silase dengan Teknik In 
Vitro. Skripsi. Institut Pertanian Bogor. Bogor.

Leng, R. A., 1991. Application of Biotechnology to Nutrition of Animals in Developing Countries. FAO Animals Production and Health Paper no 90, Rome, Italy.

Muhtarudin, Erwanto dan A. Dakhlan. 2011. Teknik Penelitian untuk Ilmu Peternakan. Aura. Bandar Lampung.

Nahak, O.R., P.K. Tahukb., G.F. Birac., A. Bered dan H. Riberue. 2019. Pengaruh penggunaan jenis aditif yang berbeda terhadap kualitas fisik dan kimia silase komplit berbahan dasar sorgum (Shorgum bicolor (L.) Moench). Journal of Animal Science 4(1): 3-5.

Preston and J. A. Leng, 1987. Drought Feeding Strategies Theory and Practice. Feel Valley Printery, New South Wales. 25(1): 15.

Rahmadi, D. 2003. Pengaruh Lama Fermentasi dengan Kultur Mikroorganisme Campuran terhadap Komposisi Kimia Limbah Kubis. J. Indon. Anim. Agric. 28(2): 90-94.
1987. Meningkatkan Pemakaian Jerami Jagung Sebagai Pakan Ternak Ruminansia Dengan Suplementasi. Bioconvertion Project Workshop on Crop Residues for Feed and Other Purposes. Grati.

Ranjhan, S. K. 1977. Management and Feeding Partices in India. Vikas Publishing Hause. Put, Ltd., New Delhi.

Stefani, J. W. H., F. Driehuis, J. C. Gottschal, and S. F. Spoelstra. 2010. Silage Fermentation Processes and Their Manipulation. Electronic Conference on Tropical Silage. Food Agricultural Organization.

Superianto, S. dan A.E. Harahap, dan A. Ali. 2018. Nilai nutrisi silase limbah sayur kol dengan penambahan dedak padi dan lama fermentasi yang berbeda. Jurnal Sain Peternakan Indonesia 13(2): 172-181.

Winarno, F.G. 1992. Kimia Pangan dan Gizi. PT. Gramedia Pustaka Utama. Jakarta. 